\title{
La gestión del riesgo en los equipos quirúrgicos de alta complejidad: el caso del Hospital Interzonal de Agudos Eva Perón
}

Risk Management in Highly Complex Surgical Teams: the Case of Hospital Interzonal de Agudos Eva Perón Gestão de riscos em equipes cirúrgicas de alta complexidade: o caso do Hospital Interzonal de Agudos Eva Perón

\section{Daiana Valeria Díaz}

Universidad Nacional de General

Sarmiento, Argentina

E-mail:ddiaz@campus.ungs.edu.ar

Fecha de Recepción: 25/05/2021 Fecha de Aceptación: 21/07/2021

Palabras clave

- gestión del riesgo - equipos quirúrgicos de alta complejidad - organizaciones de alta confiabilidad

\section{Resumen}

Estudios realizados en diversos países muestran que los servicios en los que se producen la mayor cantidad de eventos adversos son los de cirugía y que, en comparación a los países industrializados, los países en desarrollo presentan una probabilidad mayor de que se produzcan tales eventos. En Argentina, esta problemática está invisibilizada por la falta de información sobre sucesos de este tipo y la escasez de investigaciones que la abordan.

En este marco, se inserta nuestro interés por posar la mirada en la gestión del riesgo en el quirófano, abordando nuestro estudio desde las ciencias de la gestión y la administración, con el fin de estudiar las condiciones de riesgo para los pacientes, las prácticas concernientes al proceso de trabajo, los factores organizacionales que convergen en el mismo y las estrategias utilizadas por el equipo para gestionar el riesgo.

Utilizamos una perspectiva metodológica predominantemente cualitativa, cuya estrategia de investigación consistió en el estudio de caso. Consideramos el caso del Hospital Interzonal de Agudos Eva Perón como ejemplar para el estudio descriptivo de las formas en que gestionan el riesgo los equipos quirúrgicos en intervenciones de alta complejidad.

Se dio prioridad a fuentes de información primaria a partir de las técnicas de recolección de datos de observación no participante y entre- 
Keywords

- highly complex surgical teams

- highly reliable organizations

- risk management vistas en profundidad. La indagación fue complementada con fuentes de información secundaria.

Los resultados obtenidos nos permitieron aportar evidencia empírica relacionada con las situaciones críticas y riesgos del sistema, así como sobre la gestión de los mismos.

\begin{abstract}
Studies carried out in various countries show that the services in which the greatest number of adverse events occur are the surgery services and, compared to industrialized countries, developing countries have a higher probability of such events to occur. In Argentina, the lack of information related to these events and the scarcity of research on them lead to the invisibility of this predicament.

Within this framework, we are interested in looking at risk management in the operating room, with an approach from the perspective of management and administration sciences, in order to study the risk conditions for patients, the relevant practices to the work process, the organizational factors that converge in it and the strategies used by the team to manage risk.

A predominantly qualitative methodological perspective, based on case studies, was used. The case of Hospital Interzonal de Agudos Eva Perón was selected for the descriptive study of the ways in which surgical teams manage risk in highly complex interventions.

Priority was given to primary information sources based on non-participant observational data collection techniques and in-depth interviews. The inquiry was complemented with secondary information sources.

The results obtained allowed us to provide empirical evidence related to critical situations and risks in the system as well as strategies for their management.
\end{abstract}

\section{Resumo}

Estudos realizados em diversos países mostram que os serviços nos quais ocorre 0 maior número de eventos adversos são os de cirurgia e que, comparados aos países industrializados, os países em desenvolvimento têm maior probabilidade de ocorrência desses eventos. Na Argentina, esse problema é invisível devido à falta de informações sobre eventos desse tipo e à escassez de investigações que 0 abordem.

Nesse quadro, insere-se nosso interesse em observar a gestão de riscos na sala de cirurgia, aproximando nosso estudo das ciências da gestão e da administração, a fim de estudar as condições de risco para os pacientes, as práticas relativas ao processo de trabalho, os fatores organizacionais que convergem nela e as estratégias utilizadas pela equipe para gerenciar o risco.

Utilizamos uma perspectiva metodológica predominantemente qualitativa, cuja estratégia de pesquisa consistiu no estudo de caso. Conside- 
Palavras-chave

- gerenciamento de risco

- equipes cirúrgicas altamente complexas

- organizações altamente confiáveis ramos o caso do Hospital Interzonal de Agudos Eva Perón como exemplar para 0 estudo descritivo das formas como as equipes cirúrgicas gerenciam o risco em intervenções de alta complexidade.

A prioridade foi dada às fontes primárias de informação com base nas técnicas de coleta de dados observacionais não participante e entrevistas em profundidade. A indigação foi complementada com fontes de informação secundária.

Os resultados obtidos permitiram fornecer evidências empíricas relacionadas com as situações críticas e riscos do sistema, bem como a sua gestão. 